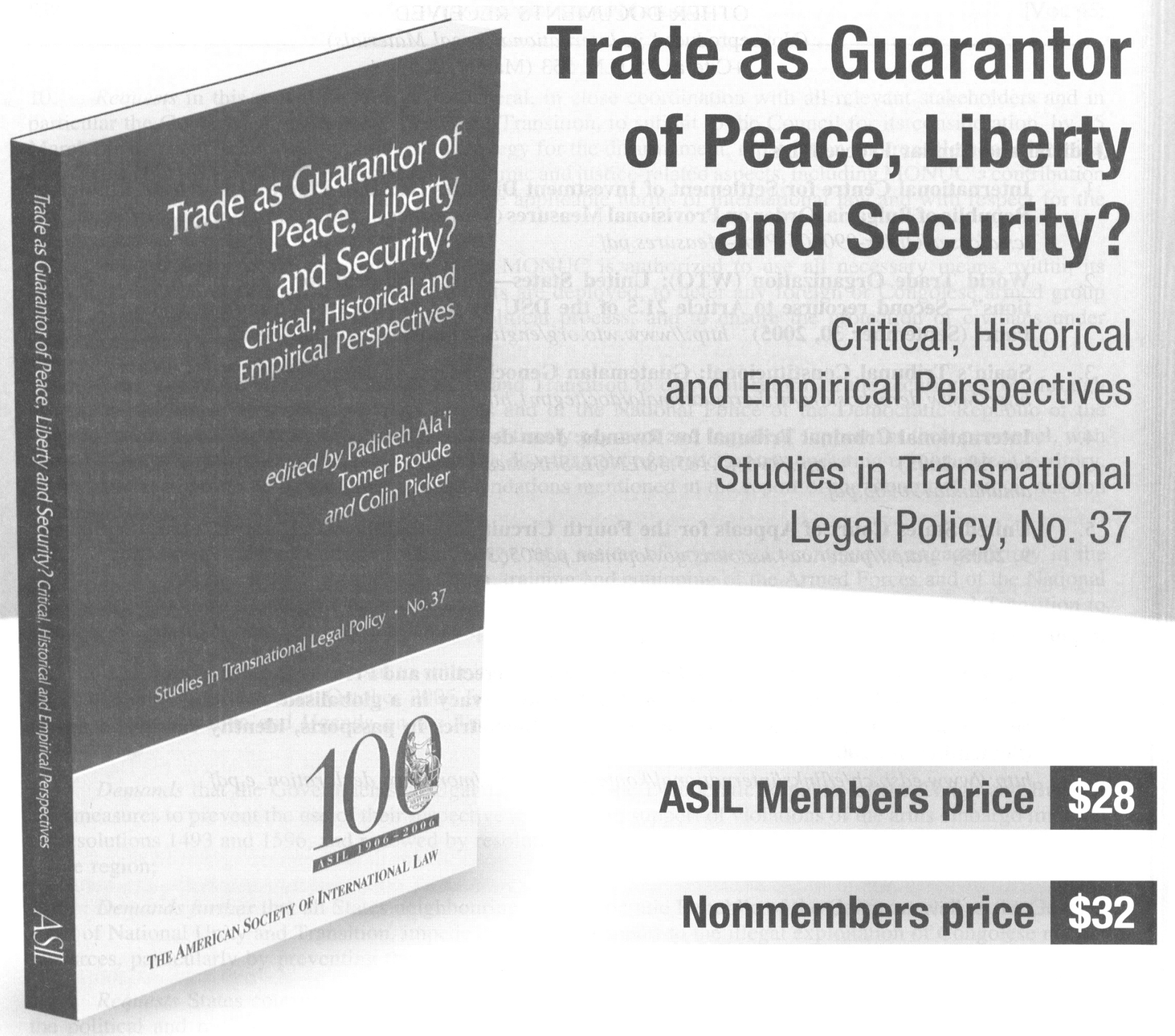

To order, please call the

William S. Hein \& Company, Inc. at 800-828-7571 (U.S) or 716-882-2600 (outside U.S.) 


\section{New Titles from Hart Publishing}

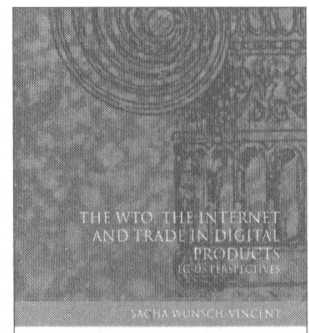

The WTO, the Internet and Trade in Digital Products

\section{EC-US Perspectives}

Sacha Wunsch-Vincent

The rapid development of the Internet has led to a growing potential for electronic trade in digital content. As a result, there is a need for a global trade framework applicable to such digitally-delivered content products. Yet, digital trade is currently not explicitly recognised by the trade rules and obligations of the World Trade Organization (WTO).

This study provides a complete analysis of the related challenges in the ongoing WTO Doha Negotiations to remedy this state of affairs.

"This important work highlights the missed opportunity in on-going global trade talks — the failure to pursue a free trade framework for digitally delivered content. If not corrected, one can readily imagine the rise of discriminatory barriers to digital trade of the type that have dogged global trade flows for years, and a failed recognition by the WTO of the reality of modern commerce. The WTO should, as the author argues, put a "spotlight" on electronic trade, and move forward in a comprehensive fashion."

Ambassador Charlene Barshefsky, Former United States Trade Representative

"Wunsch-Vincent provides a comprehensive analysis of the challenges to establish a liberal trade regime for trade in digital products. This book will become an important point-of-reference for anybody interested in e-commerce and the WTO."

Carlos A. Primo Braga, Senior Adviser, International Trade Department, The World Bank

Jan 06 Hbk I-84II3-573-9 Jan $06 \$ 100$

Studies in International Trade Law No: 3

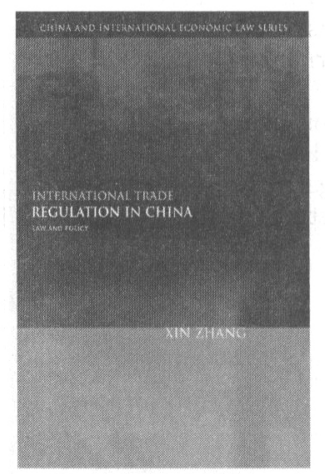

\section{International Trade Regulation in China}

Law and Policy

\section{Xin Zhang}

This book presents a comprehensive survey of Chinese legal and regulatory systems governing international trade following China's accession to the World Trade Organisation (WTO) and the coming into force of the revised PRC Foreign Trade Law. It provides a systematic and in-depth analysis on the text of applicable Chinese laws and rules, with a particular focus on their practical application. It also critically explores whether international trade regulation in China complies with the WTO Agreement both in the text and in spirit and identifies areas where improvements by Chinese trade regulators would be desirable. The book combines analysis with detailed practical advice and will be of interest to academics, practitioners and policy makers.

March 06 Hbk I-84II3-393-0 \$150

China and International Economic Law Series No: 2

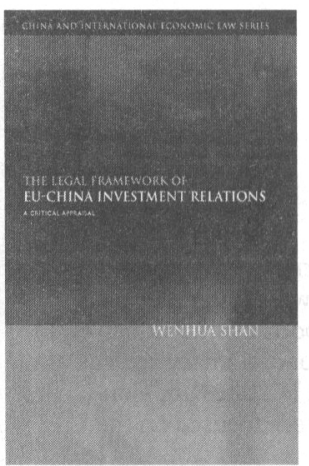

\section{The Legal Framework of EU-China Investment Relations}

\section{A Critical Appraisal}

\section{Wenhua Shan}

EU investment in China has increased dramatically since the early 1990 s and is poised to increase further in light of Chinas recent accession to the World Trade Organisation. This book explores the existing legal framework governing EU-China investment relations, particularly EU investment in China. The current legal framework is composed of Chinese law, EU law and applicable international law, but the Chinese law is unsystematic and hard to discover and the EU has acquired only shared external investment competence which is vaguely defined. The applicable international treaties are incomplete, incoherent, or either too general or too specialised. What the book demonstrates is that the time is ripe for a new international legal framework for foreign investment in China, and that as EU-China economic and political relations continue to improve, construction of such a framework is not only necessary, but also possible. October 2005 Hbk |-84||3-39|-4 \$150

China and International Economic Law Series No: I

\section{Human Rights and Religion}

\section{The Islamic Headscarf Debate in Europe} Dominic McGoldrick

The debate on multiculturalism and human rights in Europe was reignited in 2004 by the Islamic headscarf ban in France. The legal and political tensions thrown up by this debate are now being witnessed in many European states. The place of religion in schools in general, and wearing of religious dress in State schools in particular, has become an issue across Europe. Supporters of the right to wear the headscarf argue that the ban and similar prohibitions infringe a number of human rights. The book outlines the role and function of an international human rights law approach to the Islamic headscarf. The wider the frame of analysis, the deeper the significance of the headscarf ban can appear to be. The book concludes with reflections on the broader political and cultural struggles that lie behind the headscarf debate.

July 06 Pbk I-84II3-652-2 \$30 


\title{
Religion and Human Rights
}

\section{An International Journal}

\author{
Managing Editor: Nazila Ghanea
}

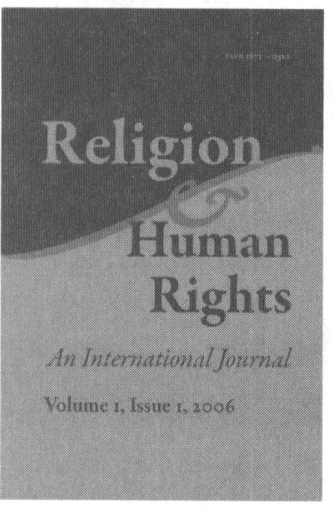

2006: Volume 1 (in 3 issues)

ISSN 1871-031X / E-ISSN 1871--0328

Institutional subscription rates

Print + e: EUR 140.- / US\$ 175.-

e-only: EUR 126.- / US\$158.-

Individual subscription rates

Print only: EUR 47.- / US\$59.-

Religion \& Human Rights provides a unique academic forum for the discussion of issues which are of crucial importance and which have global reach. The Journal covers the interactions, conflicts and reconciliations between religions or beliefs on the one hand; and systems for the promotion and protection of human rights, international, regional and national, on the other.

The Journal tackles these issues fearlessly, and draws its materials from all relevant disciplines - theology, anthropology, history, international relations, human rights, religious studies, and many others - but with special emphasis on legal frameworks. It is an indispensable source for all those concerned with monitoring, studying, teaching, analysing or developing policies on the relationship between religion and human rights today.

\section{The Hague Journal of Diplomacy}

\author{
Edited by Jan Melissen and Paul Sharp
}

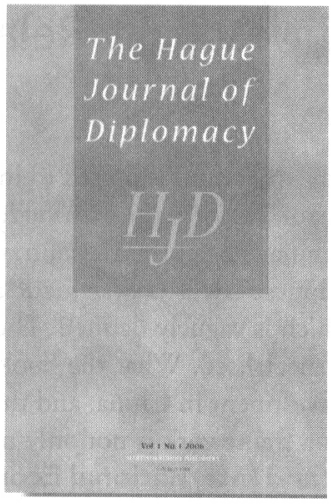

2006: Volume 1 (in 3 issues)

ISSN 1871-1901 / E-ISSN 1871-191X

Institutional subscription rates

Print + e: EUR 180.- / US\$225.-

e-only: EUR 162.- / US\$203.-

Individual subscription rates

Print only: EUR 60.- / US\$75.-

The Hague Journal of Diplomacy aims to be the premier research journal for the study of diplomacy and its role in contemporary international relations. It will publish the best research on the theory, practice and technique of diplomacy in both its traditional state-based bilateral and multilateral forms, plus more recent forms of diplomacy such as track-two diplomacy, field diplomacy and public diplomacy practised by states and nonstate entities. Each issue contains research articles and at least one piece focused on the practical aspects of diplomatic experience.

The Hague Journal of Diplomacy seeks to promote the analysis and understanding of diplomacy by acquainting a broad readership with the best works being undertaken in diplomatic studies in a variety of intellectual traditions. Diplomatic studies is an inter-disciplinary and inclusive field. The Hague Journal of Diplomacy is therefore open to the wide array of methodologies by which diplomacy may be studied. The Hague Journal of Diplomacy's readership will first of all be universities and think tanks, in particular researchers, teachers and graduate students of International Relations, together with educators and trainees on programmes in Diplomatic Studies. Secondly, The Hague Journal of Diplomacy is a journal for everyone with an interest or stake in firstrate and accessible articles on all aspects of diplomacy, not least the world's foreign ministries and diplomatic academies. 


\section{Editor-in-Chief: Malgosia Fitzmaurice}

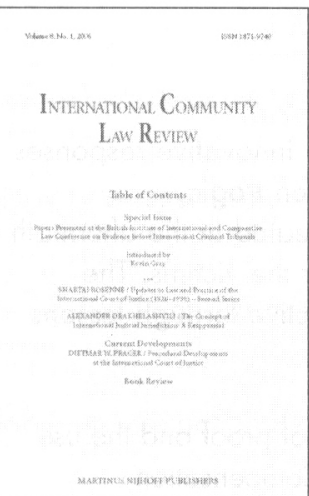

2006: Volume 8 (in 3 issues)

ISSN 1871-9740 / E-ISSN 1871-9723

Institutional subscription rates

Print + e: EUR 199.- / US\$ 249.

e-only: EUR 179.- / US\$224.-

Individual subscription rates

Print only: EUR 66.- / US\$82.

"International law can only prosper if careful attention is given to all the voices expressing themselves on current legal issues [...]. Any striving for hegemony threatens to undermine the legitimacy of international law."

From the Foreword by Christian Tomuschat and Jean-Marc Thouvenin to The

Fundamental Rules of the International Legal Order: Jus Cogens and Obligations Erga Omnes.

Merging Non-State Actors and International Law (ISSN 1567-7125) and the International Law FORUM du droit international (ISSN 1388-9036), the International Community Law Review (ICLR) addresses all aspects of international law and the international community. The journal aims to explore the implications of various traditions of international law, as well as more current perceived hegemonic trends, for the idea of an international community. The journal will also look at the ways and means in which the international community uses and adapts international law to deal with new and emerging challenges. Non-state actors - intergovernmental and non-governmental organisations, individuals, peoples, transnational corporations and civil society as a whole - have changed our outlook on contemporary international law. In addition to States and intergovernmental organizations, they now play an important role.

Rather than regional, the focus of ICLR will be multicultural, including alternative and/or critical approaches, with contributions written by scholars from all parts of the globe.

The International Community Law Review, published three times a year, will consist of articles, shorter articles/ comments, case notes and book reviews.

\section{NEW LOOSE-LEAF SERVICE}

\section{International Kidnapping}

\section{The Hague Convention on the Civil Aspects of International Child Abduction}

Edited by Louis Garb

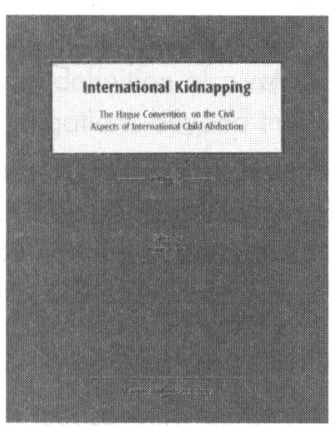

least highly persuasive value.

The collection will be updated and expanded at regular intervals

For our Conditions of Sales please see www.brill.nl

B R L L

\author{
- December 2005 \\ - ISBN 9004149295 \\ - Loose-leaf service (145 pp.) \\ - List price EUR 150.- / US\$203.- \\ - International Kidnapping
} or cs@brillusa.com (for customers in North America).
The Hague Convention on the Civil Aspects of International Child Abduction is a remarkable document, which has had significant impact on child protection policies in much of the world. This new collection provides a comprehensive handbook to the practice in litigation involving the Convention in the countries where the Convention has had the greatest impact and litigated cases have been most numerous.

In a time when the role of citation to foreign courts is one of intense controversy, this is an area where the practice of foreign courts and foreign governments is most relevant and valuable, as the very subject matter requires a consideration of the law of more than one country, and the interpretation of a common document by differing courts is of at

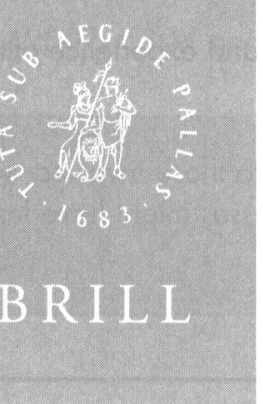

M A R T I N U S

To order and for more information e-mail brill@turpin-distribution.com
NIJHOFF

P U B L I S H E R S 


\section{NEW TITLES ON MASS CLAIMS FROM OXFORD}

\section{REDRESSING INJUSTICES THROUGH MASS CLAIMS PROCESSES INNOVATIVE RESPONSES TO UNIQUE CHALLENGES}

Edited by The International Bureau of the Permanent Court of Arbitration

This volume from the International Bureau of the PCA presents a collection of studies on innovative responses to the unique challenges of resolving large numbers of claims arising from common, often tragic, circumstances-mass claims. The mass claims processes discussed in this volume were created in the aftermath of war or other atrocities, and redress is often an important component of settlement for the victims. The authors consider mass claims processes both from a conceptual and a practical perspective through lessons learned over twenty-five years.

This book covers innovations to speed mass claims processes by means of new standards of proof and the use of information technology, as well as specific mass claims processes: the United Nations Compensation Commission; the Austrian General Settlement Fund; the French Commission for the Compensation of Victims of Spoliation; the German Forced Labour Compensation Programme; and the reparations provisions of the Statute of the International Criminal Court. From a North American perspective, authors address the litigation of mass claims involving slavery under United States law, the United States Indian Claims Commission, and the successful completion of the September 11 th Victim Compensation Fund. In addition, Volume 1 of the Final Report of the Special Master of the September 11 th Victim Compensation Fund is reprinted in its entirety.

The responses of the international community to current issues of compensation and reparations, the role of civil society actors in reparations legislation, and recent instruments adopted by the Council of Europe and the United Nations Commission on Human Rights are also reviewed.

April $2006 \cdot 544$ pages $\bullet$ 0-19-929793-2 $\bullet$ Hardback $\bullet \$ 110.00$

\section{INTERNATIONAL MASS CLAIMS PROCESSES}

\section{LEGAL AND PRACTICAL PERSPECTIVES}

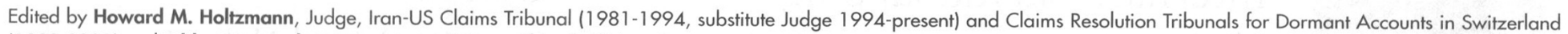

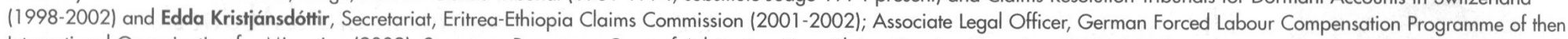

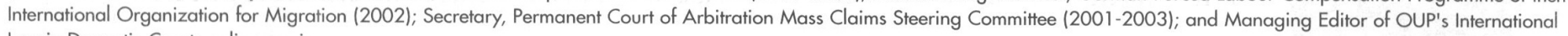
Law in Domestic Courts online service.

Mass Claims Processes have become been increasingly important phenomena in international dispute resolution. This is the first book to provide comprehensive information for a systematic comparison and analysis of the legal issues and practical matters involved in their establishment and operation.

This book considers eleven of the highest profile modern Mass Claims tribunals and commissions created to redress large-scale losses. They include the Iran-US Claims Tribunal, the UN Compensation Commission (relating to Iraq's invasion of Kuwait), several bodies to resolve claims relating to bank accounts, insurance or slave labor resulting from the Holocaust, as well as to the conflicts in Bosnia and Herzegovina and in Kosovo, and to the war between Eritrea and Ethiopia. The Processes described in this book received claims involving an estimated aggregate of more than 4 million persons and entities seeking over US \$4 billion.

The book identifies and focuses on forty-seven basic topics that experience shows typically arise with respect to international Mass Claims Processes, offering descriptions and commentary on the ways in which the various Processes have approached each topic.

Much of the information gathered in this book is not publicly available elsewhere and is based on the knowledge and experience of experts who have either served on the Processes or otherwise been directly engaged in their activities.

This book should be useful to all scholars and practitioners interested in international dispute settlement as well as to those involved with new or existing Mass Claims Processes. Moreover, it may lead to recognition that certain aspects of Mass Claims Processes might have lessons for other procedures for resolution of complex commercial or diplomatic disputes.

October $2006 \bullet 550$ Pages • 0-19-920744-5 • Hardback • \$165.00

\section{OXFORD}




\section{NEW TITLES ON REFUGEE LAW FROM OXFORD}

\section{THE REFUGEE IN INTERNATIONAL LAW}

\section{THIRD EDITION}

2rofessor Guy Goodwin-Gill, Professor of International Refugee Law University of Oxford, and Senior Research Fellow,

All Souls College, University of Oxford

And Dr. Jane McAdam, Lecturer, Faculty of Law, University of Sydney

Reviews of the second editon:

"a thoughtful and comprehensive treatise [that] illustrates profound and careful scholarship."

- Immigration \& Nationality Law \& Practice

"the most authoritative text available on international refugee law."

-Refugee Reports

Millions of people are today forced to flee their homes as a result of conflict, systematic discrimination, or other forms of persecution. The core instruments on which they must rely to secure international protection are the 1951 Convention Relating to the Status of Refugees and its 1967 Protocol. This book, the leading text in the field, examines key challenges to the Convention, through logically examining the status of refugees, applications for asylum, and finally the international and domestic standards of protection.

The situation of refugees is one of the most pressing and urgent problems facing the international community and refugee law has grown in recent years to a subject of global importance. In this long-awaited third edition each chapter has been thoroughly revised and updated and every issue, old and new, has received fresh analysis. Features include: analysis of internally displaced persons; so-called preventive protection; access to refugees; safety of refugees and relief personnel; the situation of refugee women and children; a detailed examination of the role of the UNHCR and the Palestinian situation; an assessment of the protection possibilities (or lack of them) in the European Convention on Human Rights; and the EU's Qualification Directive in 2004.

November $2006 \cdot 600$ Pages • 0-19-920763-1 • Paperback • $\$ 55.00$

0-19-928130-0 • Hardback • \$125.00

\section{COMPLEMENTARY PROTECTION IN INTERNATIONAL REFUGEE LAW}

Jane McAdam, Lecturer, Faculty of Law, University of Sydney

This book is the first dedicated study on 'complementary protection' the protection afforded by States to persons who need international protection but fall outside the legal definition of a refugee in article 1A(2) of the 1951 Refugee Convention. Human rights law has extended States' international protection obligations beyond the Refugee Convention, preventing States from removing individuals who would be at risk of serious harm if returned to their countries of origin. While a number of States have traditionally respected these additional human rights obligations, they have been reluctant to grant beneficiaries a formal legal status analogous to that enjoyed by Convention refugees. This book provides a comprehensive analysis of complementary protection, from its historical development through to its contemporary application. By examining the human rights foundations of the Convention, the architecture of Convention rights, regional examples of complementary protection, and principles of non-discrimination, the book argues that the Convention acts as a type of lex specialis for persons in need of international protection, providing a specialized blueprint for legal status, irrespective of the legal source of the protection obligation.

Oxford Monographs in International Law

February $2007 \cdot 304$ pages • 0-19-920306-7 • Hardback • \$110.00

PRICES ARE SUBJECT TO CHANGE AND APPLY ONLY IN THE US.

TO ORDER, OR FOR MORE INFORMATION, PLEASE CALL 1800451 -7556.

IN CANADA, CALL 1800 387-8020. VISTT OUR WEBSITE AT WWW.OUP.COM 


\section{$\$ 13$ billion in claims have been brought under NAFTA Chapter 11 in the last 3 years. \\ Make Sure You Get Your Share!}

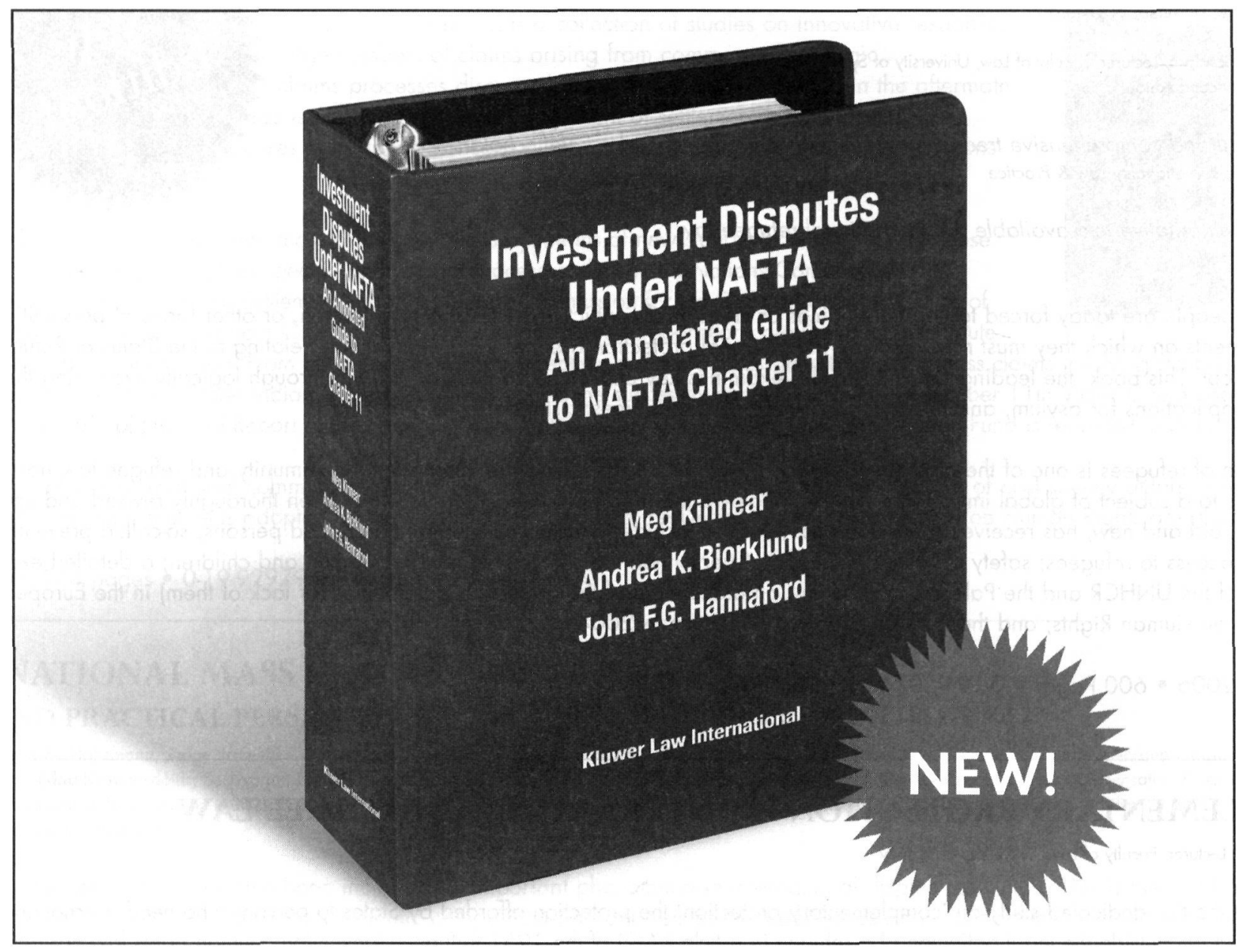

With $\$ 13$ billion in claims brought under NAFTA Chapter 11 in the last 3 years, public and professional interest in this topic has been growing significantly.

Investment Disputes Under NAFTA from Kluwer Law International is the only publication that improves your chances of winning a NAFTA Chapter 11 dispute with the U.S., Canadian or Mexican government by delivering:

- Succinct, expert commentary on all 39 articles of NAFTA Chapter 11

- The insights of expert authors who were actually involved in drafting NAFTA

- A valuable collection of key case law that has come down with regard to Chapter 11-organized by Article

- Accurate and thorough cross-referencing to help you easily find all relevant material

- Logical organization of all materials as well as a complete Index and Table of Cases
Combining expert commentary with complete primary source materials and case law, Kluwer Law International's Investment Disputes Under NAFTA is the must-have resource for anyone planning or already involved in-a Chapter 11 claim.

\section{Pursue Your Interests...Protect Your Rights...Recover Losses.}

\section{See us at ASIL 2006 www.aspenpublishers.com 1-800-638-8437 \\ - Wolters Kluwer Law \& Business}

Kluwer Law International is now part of Wolters Kluwer Law \& Business. We continue to provide the global legal community with reliable international law information in English. 


\section{New Titles from Kluwer Law International! See us in Washington, DC at the ASIL 2006 Conference}

\section{Stop by Booth \#15 and Save 15\%!}

A Guide to the ICC Rules of Arbitration, Second Edition By: Yves Derains \& Eric A. Schwartz Casebound

ISBN: $9041122680, \$ 224$

Published: November 2005

Unfair Competition Law: European Union and Member States INTERNATIONAL COMPETITION LAW SERIES

By: Frauke Henning-Bodewig Casebound

ISBN: $9041123296, \$ 134.50$

Published: February 2006

Introduction to Polish Law INTRODUCTION OF THE LAW SERIES By: Dr. Stanislaw Frankowski Casebound

ISBN: $9041123318, \$ 186$

Published: December 2005

How to Hire and Fire in 76 Jurisdictions

By: Erik van Emden, Jon Heuvel and Marie-Laure Labat-Oliveau Casebound

ISBN: $9041123350, \$ 128$

Published: October 2005

New Horizons for International Commercial Arbitration and Beyond

CONGRESS SERIES

By: Albert Jan van den Berg

Casebound

ISBN: $9041123482, \$ 154$

Published: September 2005
Provisional Measures in International Commercial

Arbitration

By: Ali Yesilirmak

Casebound

ISBN: $9041123539, \$ 141$

Published: September 2005

Sustainable Development in World Trade Law

By: Markus W. Gehring and

Marie-Claire Cordonier Segger

Casebound

ISBN: 9041123660, \$179

Published: October 2005

Yearbook Commercial Arbitration

Volume XXX-2005

YEARBOOK COMMERCIAL

ARBITRATION SERIES

Softcover

ISBN: 9041124039 , \$268

Published: January 2006

Swiss Rules of International

Arbitration: Commentary

By: Tobias Zuberbuhler, Christoph

Muller, and Philipp Habegger

Casebound

ISBN: 904112411X, \$135

Published: October 2005

Women in Academia \& Equality Law: Aiming High - Falling Short? BULLETIN OF COMPARATIVE LABOUR RELATIONS SERIES

By: Anne Numhauser-Henning Softcover

ISBN: $9041124276, \$ 115.20$

Published: February 2006
Comparative Law Yearbook of International Business,

Volume 27-2005

COMPARATIVE LAW YEARBOOK SERIES

Casebound

ISBN: $9041124314, \$ 230$

Published: December 2005

General Clauses and Standards in European Contract Law:

Comparative Law, EC Law and

Contract Law Codification

PRIVATE LAW EUROPEAN

CONTEXT SERIES

Type Casebound

ISBN: $9041124322, \$ 128$

Published: December 2005

Complex Arbitrations: Multiparty,

Multi-contract, Multi-Issue and

Class Actions

INTERNATIONAL ARBITRATION

LAW LIBRARY SERIES

By: Bernard Hanotiau

Casebound

ISBN:904112442X, \$166

Published: February 2006

Harmful Tax Competition

in the European Union

By: Ben J. Kiekenbeld

Casebound

ISBN: $9041124470, \$ 96$

Published: Janaury 2006

Theory and Practice of International and Internationalized Criminal Proceedings

By: Geert-Jan Knoops

Casebound

ISBN: $9041124578, \$ 90$

Published: December 2005

\section{Review These New Titles Yourself...}

Then Save $15 \%$ on All Purchases!

Visit us at ASIL and Save 15\%

www.aspenpublishers.com = 1-800-638-8437

\section{Wolters Kluwer}

Law \& Business

Kluwer Law International is now part of Wolters Kluwer Law \& Business.

We continue to provide the global legal community with reliable international law information in English. 


\section{OUTSTANDING SCHOLARSHIP}

\section{The Impact of Human Rights Law on Armed Forces \\ Peter Rowe}

This book considers those aspects of human rights law which may become relevant to the activities of armed forces whether they remain in barracks, undertake training or are deployed in military operations within their own state or outside it. The unique nature of military service and of military courts gives rise to human rights issues in respect both of civilians and soldiers, whether volunteers or conscripts, who find themselves before these courts. Rowe examines these issues as well as the application of international humanitarian law alongside the human rights obligations of the state when forces are training for and involved in armed conflict; where armed forces are deployed in situations of civil disorder; and where states contribute armed forces to multinational forces.

\$95.00: Hardback: 0-521-85170-X: 272pp

\$45.00: Paperback: 0-521-61732-4

\section{Non-Governmental Organizations \\ in International Law}

Anna-Karin Lindblom

Non-governmental organizations (NGOs)

play an increasing political role on the international scene, and their position in relation to international law is generally regarded as important but informal. Their actual legal status has not been the subject

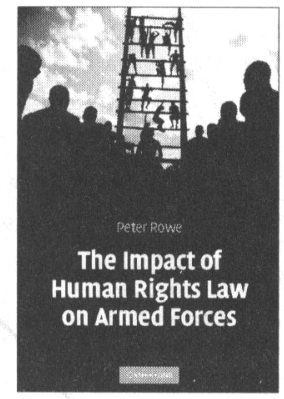
of much investigation. This book examines the legal status of NGOs in different fields of international law, with emphasis on human rights law. By means of a thorough examination and systematization of international legal rules and practices, the rights, obligations, locus standi and consultative status of NGOs are explored. This study is placed within a wider discussion on the representation of groups in the international legal system. Lindblom argues, on the basis of a discourse model of international decision-making, that non-governmental organization is an important form of public participation that can strengthen the flawed legitimacy of the state-centric system of international law.

\$120.00: Hardback: 0-521-85088-6: 586pp

\section{Coming in Spring 2006!}

\section{International Relations \\ The Path Not Taken}

Thomas J. Schoenbaum

This book addresses the main aspects of International Relations including the theoretical foundations of the subject and reform of the United Nations and international institutions. Chapters are devoted to solving particular world problems including globalization and the world economy, terrorism, nuclear proliferation, protection of the environment and securing human rights.

\$70.00*: Hardback: 0-521-86280-9: c.320pp

\$28.99*: Paperback: 0-521-68150-2

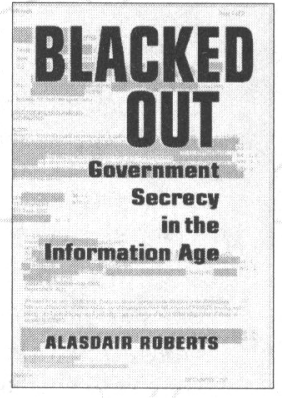

\section{Blacked Out}

Government Secrecy in the Information Age Alasdair Roberts

Alasdair Roberts, an international authority on transparency in government, examines the evolution of the trend toward governmental openness and how technological developments have assisted the disclosure and dissemination of information. In the process he provides a guide to those areas where the global battle over secrecy is most intense. Drawing on cases from many different countries, Roberts shows how such powerful trends as privatization, globalization, and the "networking" of security agencies are complicating the fight against secrecy.

\$30.00: Hardback: 0-521-85870-4: 336pp

\section{Transboundary Harm in International Law} Lessons from the Trail Smelter Arbitration Edited By Rebecca Bratspies and Russell Miller

Many harms flow across the ever-more porous sovereign borders of a globalizing world. These harms expose weaknesses in the international legal regime built on sovereignty of nation states. Using the Trail Smelter Arbitration, one of the most cited cases in international environmental law, this book explores the changing nature of state responses to transboundary harm. Taking a critical approach, the book examines the arbitration's influence on international law generally, and international environmental law specifically.

\$100.00*: Hardback: 0-521-85643-4: c.400pp 


\section{FROM CAMBRIDGE}

The UN International Criminal Tribunals The Former Yugoslavia, Rwanda and Sierra Leone

William A. Schabas

This book is a guide to the law that applies in the three international criminal tribunals, for the former Yugoslavia, Rwanda and Sierra Leone, set up by the UN during the period 1993 to 2002 to deal with atrocities and human rights abuses committed during conflict in those countries. Building on the work of an earlier generation of war crimes courts, these tribunals have developed a sophisticated body of law concerning the elements of the three international crimes (genocide, crimes against humanity and war crimes), and forms of participation in such crimes, as well as other general principles of international criminal law, procedural matters and sentencing. The legacy of the tribunals will be indispensable as international law moves into a more advanced stage, with the establishment of the International Criminal Court.

\$150.00: Hardback: 0-521-84657-9: 774pp

\$75.00: Paperback: 0-521-60908-9

\section{International Human Rights and Humanitarian Law}

Edited By Francisco Forrest Martin, Stephen J. Schnably, Richard Wilson, Jonathan Simon, and Mark Tushnet

This volume introduces law students to the international legal instruments and case law governing the substantive and procedural dimensions of international human rights and humanitarian law, including economic, social, and cultural rights. It also discusses the history and organizational structure of human rights and humanitarian law enforcement mechanisms.

\$95.00: Hardback: 0-521-85886-0: 1,008pp

\section{The 'War on Terror' and the Framework of International Law} Helen Duffy

This book sets out the essential features of the international legal framework against which the ' $9 / 11$ ' attacks and the lawfulness of measures taken in response thereto fall to be assessed. It addresses, in an accessible manner, relevant law in relation to: 'terrorism', questions as to 'responsibility' for it, the criminal law framework, lawful constraints on the use of force, the humanitarian law that governs in armed conflict, and international human rights law.

\$110.00: Hardback: 0-521-83850-9: 540pp

\$50.00: Paperback: 0-521-54735-0

\section{Truth Commissions and Procedural Fairness}

Mark Freeman

This is the first law book entirely devoted to the subject of truth commissions. It sets forth standards of procedural fairness aimed at protecting the rights of those who come into contact with truth commissions - primarily victims, witnesses, and perpetrators. The aim of the book is to provide recommended criteria of procedural fairness for five possible components of a truth commission's mandate: the taking of statements, the use of subpoenas, the exercise of powers of search and seizure, the holding of victim-centered public hearings, and the publication of findings of individual responsibility in a final report.

\$100.00*: Hardback: 0-521-85067-3: c.300pp \$29.99*: Paperback: 0-521-61564-X

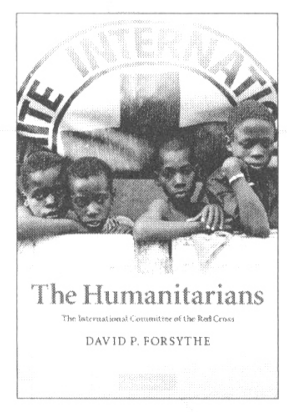

The Humanitarians The International Committee of the Red Cross David P. Forsythe

The International Committee of the Red Cross (ICRC) coordinates the world's largest private relief system for conflict situations. Its staff operates throughout the world, and in recent years the ICRC has mounted large operations in the Balkans and Somalia. Yet, despite its very important role, its internal workings are mysterious and often secretive. This book examines the ICRC from its origins in the middle of the nineteenth century until the present day, and provides a comprehensive overview of a unique private organization.

\$75.00: Hardback: 0-521-84828-8: 372pp \$31.99: Paperback: 0-521-61281-0

\section{WTO Appellate Body Repertory of Reports and Awards 1995-2004}

\section{Compiled by Appellate Body Secretariat}

The WTO Appellate Body Repertory of Reports and Awards was initially developed as an internal research tool to assist the Appellate Body Secretariat in carrying out its duty to provide legal support to Appellate Body Members. The Repertory is now being made available to the public in the hope that it will become a practical tool for officials from WTO Members. It will also assist academics, students and private practitioners of international trade law and dispute settlement.

\$130.00: Hardback: 0-521-85072-X: 774pp 


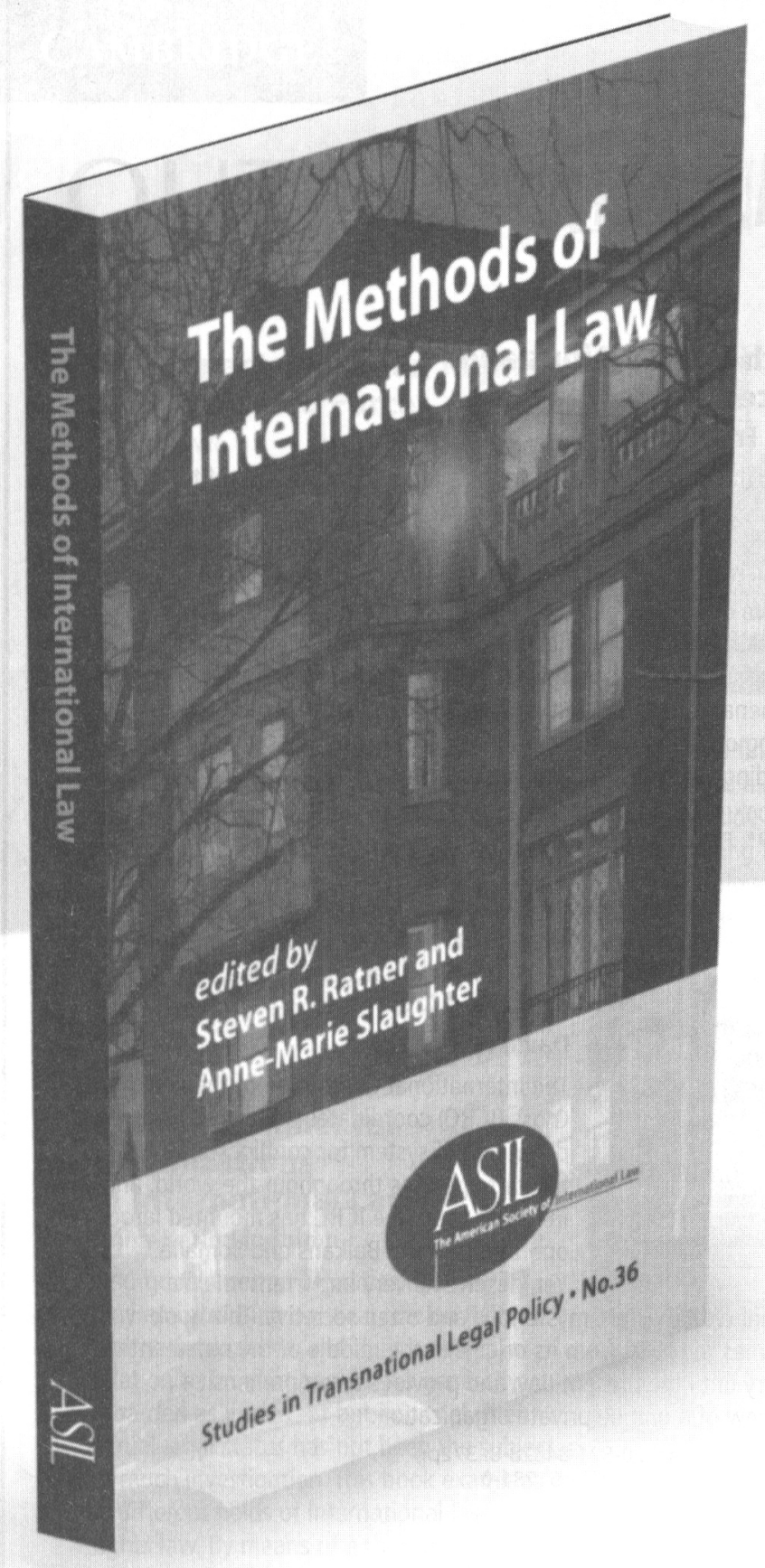

STUDIES IN TRANSNATIONAL LEGAL POLICY:

\section{THE METHODS OF} INTERNATIONAL LAW

Fourteen leading scholars from around the world detail their respective approaches to international law. With each method applied to a specific international law question, such as limitations on a state's ability to prosecute foreigners for crimes committed abroad against other foreigners, The Methods of International Law, edited by Steven Ratner and Anne-Marie Slaughter, is an exceptional tool for classroom use. Contributors include Kenneth W. Abbott, Antony Anghie, Hilary Charlesworth, B.S. Chimni, Jeffrey L. Dunoff, Martti Koskenniemi, Mary Ellen 0'Connell, Andreas L. Paulus, Steven Ratner, Bruno Simma, Anne-Marie Slaughter, Joel P. Trachtman, Siegfried Wiessner, and Andrew R. Willard. This volume updates and expands upon Appraising the Methods of International Law: A Prospectus for Readers, a symposium published in the April 1999 issue of the American Journal of International Law.

\title{
ORDER "THE METHODS OF INTERNATIONAL LAW" TODAY FOR ONLY \$32!
}

\author{
To learn more about and order "The Methods of International Law", \\ visit the ASIL Web site at www.asil.org.
}




\section{Introducing a NEW Landmark Review Series}

\section{Annual Review of Law and Social Science ${ }^{\text {tm }}$}

Volume 1, December 2005-Available Online and in Print

Editor: John Hagan, Northwestern University

Associate Editors: Kim Lane Scheppele, Princeton University

Tom R. Tyler, New York University

The Annual Review of Law and Social Science, published in December 2005, strives to enhance the understanding of the complex connections between law, culture, and society by focusing on social scientific studies of law and law-like systems of rules, institutions, processes, and behaviors. This groundbreaking series provides multidisciplinary insights into the impact of law, aggregated human behavior and interactions, analytic and normative jurisprudence, the dynamics of decision making and enforcement of authoritative rules, as well as the variations and changes in legal institutions and the management of social change by these institutions.

Volume 1 specifically addresses criminal disenfranchisement, comparative study of criminal punishment, transnational human rights, economic theories of settlement bargaining, the death penalty, law, race, and education in the United States, law and corporate governance, and more.

The Annual Review of Law and Social Science is the ideal resource for legal scholars, sociologists, political scientists, and criminologists, as well as those involved in criminal justice or social welfare departments, penal systems, judicial review, or public policy.

\section{Access This Series Online NOW at www.annualreviews.org/go/ilm2}

ASIL Members: Order TODAY and SAVE 20\%! Annual Review of Law and Social Science |Volume 1 | December 2005 | ISSN: 1550-3585 | ISBN: 0-8243-4101-5

ASIL Member Individual Price (US/Int'I): $\$ 60.80 / \$ 64.80$ Mention priority source code JALMA06 when placing your order. Regular Individual Price (US/Int'I): \$76/\$81 | Handling and applicable sales tax additional. Contact Annual Reviews for institutional pricing and site license options.
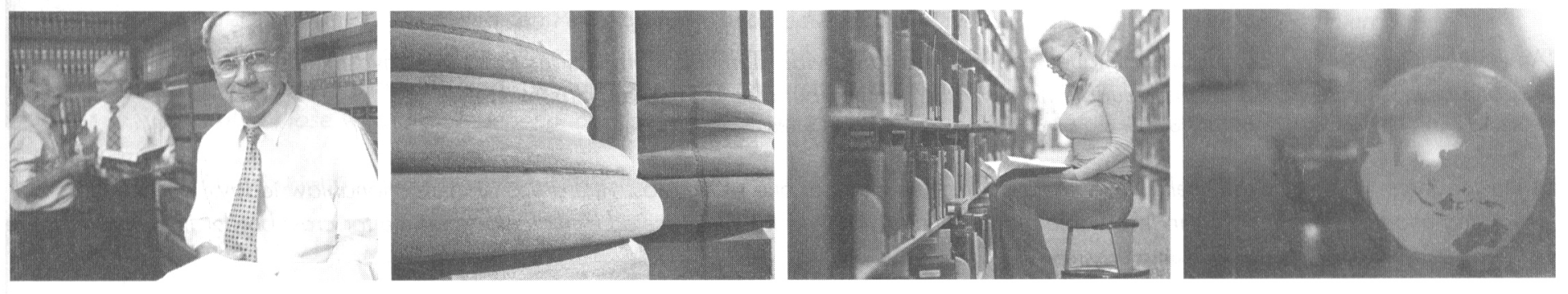

Annual Reviews

A Nonprofit Scientific Publisher

Call toll free (US/CAN): 800.523.8635 | Call worldwide: 650.493.4400

Fax: 650.424.0910 |Email: service@annualreviews.org | Online at www.annualreviews.org 


\section{NEW INTER NATIONAL COMMERCIAL ARBITRATION}

\section{Investor-State Arbitration}

Christopher Dugan, Paul, Hastings, Janofsky \& Walker LLP

Noah Rubins, Freshfields Bruckhaus Deringer

The increasing importance of international investment has been accompanied by the rapid development of a new field of international law that defines the obligations of host states towards foreign investors and creates procedures for resolving disputes in connection with those obligations. Investor-State Arbitration examines the international treaties that give investors a right to arbitration of claims, the most commonly employed arbitration rules, and the most important elements of investor-state arbitration procedure, including tribunal composition, jurisdiction, evidence, award, and challenge of annulment.

July $2006 \cdot 0-379-21544-6 \cdot \$ 165.00$

\section{Judicial Review of Commercial Arbitration Awards in the United States}

Louis B Kimmelman, O'Melveny \& Myers

Dana C. MacGrath, O'Melveny \& Myers

There is a growing body of law relating to the procedures and substantive issues that arise when U. S. courts are asked to confirm or set aside U.S. or international arbitral awards. This important practice guide provides a roadmap for initiating and prosecuting enforcement proceedings. This concise volume offers expert analysis of the necessity of judicial review of arbitration awards, the legal framework for review, and drafting considerations for both domestic and international arbitration agreements.

January $2007 \cdot 0-379-21524-1 \cdot \$ 185.00$

\section{Due Process in International Commercial Arbitration}

Matti S. Kurkela, Hannes Snellman, Helsinki and University of Helsinki

This unique guide aids arbitration counsel and arbitrators alike by identifying a uniform universal procedural code for international commercial arbitration. Moving beyond institution or jurisdictionally specific analysis to the global, this treatise examines and reconciles the principles of international due process as they continue to emerge. More than just a useful exercise, this approach of finding a unifying arbitration principle in light of the diversity of national traditions is expected to become the standard procedure in arbitral law.

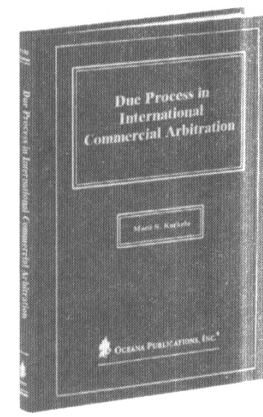

\section{International Investment, Political Risk and Dispute Resolution: A Practitioner's Guide}

Noah Rubins, Freshfields Bruckhaus Deringer

N. Stephan Kinsella, Applied Optoelectronics, Inc.

"An excellent account of how legal techniques can be used to provide significant protections to foreign investment. It is one of those rare books that is valuable not only for practice but also for the law classroom."

-Dan Sarooshi, Herbert Smith Associate Professor of International Law, University of Oxford; Barrister, London

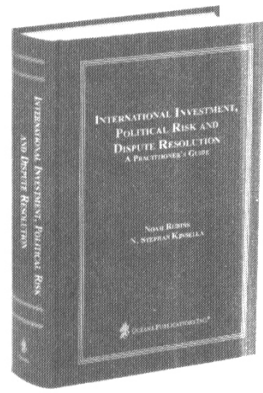

"A tour de force. Rubins and Kinsella have written a first-rate study of one of the most vital areas of international law today. (S)cholars as well as practicing attorneys will find this an invaluable guide to understanding the multifaceted adjudicatory regime for cross-border investment disputes."

-William (Rusty) Park, Professor of Law, Boston University

$2005 \cdot 0-379-21522-5 \cdot \$ 150.00 \cdot 769$ pages 


\section{Transatlantic Commercial Litigation \& Arbitration}

John Fellas, Hughes Hubbard \& Reed LLP

"(A) valuable addition to the libraries of practitioners dealing with transatlantic disputes."

- Carol Mulcahy, Berwin Leighton Paisner, London, Business Law International

Transatlantic Commercial Litigation and Arbitration is the only publication to deal specifically with transatlantic disputes involving entities in the United Kingdom and the United States. Despite a common legal heritage, there are fundamental differences between the processes of dispute resolution in each of these two countries. This book contrasts and compares those differences so that those engaged in transatlantic business understand in advance the risks of litigation in the other country.

$2004 \cdot 0-379-21423-7 \cdot \$ 155.00 \cdot 688$ pages

\section{International Commercial Arbitration in Latin America:} Regulations and Practice in MERCOSUR and the Associated Countries

Jan Kleinheisterkamp, HEC School of Management, Paris

"Time and again, the comprehensiveness of the material considered and the high density of the analysis are striking, both signs of the depth of the research... The book should become a standard work in its field, providing access to Latin American arbitration for many outsiders."

- Jürgen Basedow, Director of the Max-Planck-Institute of Foreign Private and Private International Law, Hamburg

International commercial arbitration has undergone fundamental changes in most countries of Latin America in the last decade, especially in the countries of the MERCOSUR and the associated countries. This manual provides practitioners and scholars alike with quick access to and in-depth analysis of the laws of Argentina, Bolivia, Brazil, Chile (including the new law on international commercial arbitration of September 2004), Paraguay, and Uruguay, as well as of the relevant international treaties, such as the MERCOSUR-Agreements of 1998.

$2005 \cdot 0-379-21536-5 \cdot \$ 185.00 \cdot 753$ pages

\section{International Chamber of Commerce Arbitration, Third Edition}

Jan Paulsson, Freshfields, Paris

William W. Park, Boston University School of Law

W. Laurence Craig, Coudert Freres, Paris

"An indispensable volume for any lawyer interested in the arbitration of business disputes... The value of the third edition...is enhanced by its clarity, thoroughness, numerous appendices and tables and its Rules."

-Edward D. Re, Chief judge Emeritus of the United States Court of International Trade, New York Law Journal

"This leading textbook on ICC Arbitration gets better and better with each edition... Technically the book is excellent, including a welcomed improved index."

- John Dorter, Building and Construction Law

"...W. Lawrence Craig, William W. Park and Jan Paulsson have updated their definitive work on a major institution of international arbitration, the International Chamber of Commerce Court of Arbitration. The book is now an invaluable guide to practices applicable to international arbitration and is especially indispensable for those involved in International Chamber of Commerce arbitrations. The book should also be useful to those who draft international contracts or need to include an International Chamber of Commerce arbitration clause in an agreement..."

-Richard M. Mosk, Judge Iran-United States Claims Court, Los Angeles Daily Journal

$2000 \cdot 0-379-21392-3 \cdot \$ 165.00 \cdot 952$ pages 


\section{Meet your new research team.}

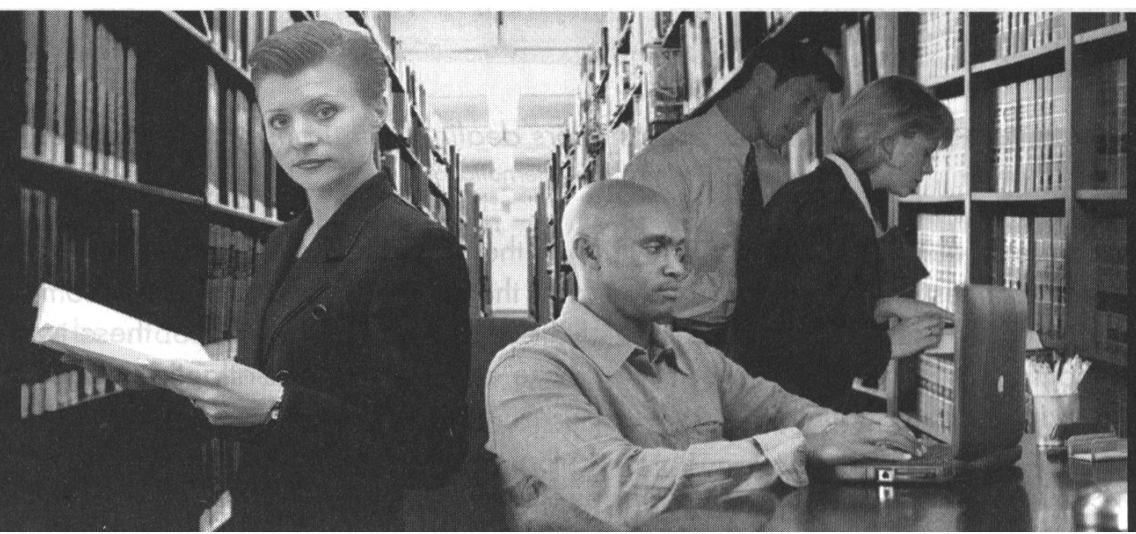

A team of experienced librarians and legal research experts is working for you, and you didn't even know it. Better yet, you can call on them 24 hours a day, seven days a week.

The EISIL team has broken down the complicated world of researching international law into 13 broad categories covering 300 international law topics. At www.eisil.org, you'll have easy access to:

- Primary source documents such as treaties and agreements.

- Information for cite checking international legal materials for articles, briefs, and working papers.

- The best web sites and other tools for doing further research on an international topic.

Research that used to take days or hours and required an extensive library can now be done in minutes!

Try it. EISIL is fast, easy and FREE. Your team of researchers is waiting.

\section{Check out EISIL today at www.eisil.org}

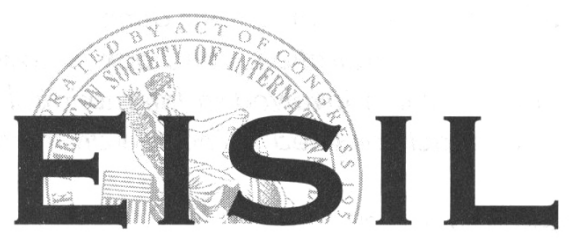

Electronic Information System for International Law

EISIL was developed by the American Society of International Law under a grant from the Andrew W. Mellon Foundation. 